\title{
Elderly people's experiences in emergencies through access to other levels of health care
}

\author{
Vivido pelo idoso nas emergências pelo acesso para outros níveis de atenção à saúde
}

Experimentado por los ancianos en situaciones de emergencia debido al acceso a otros niveles de satención de la salud

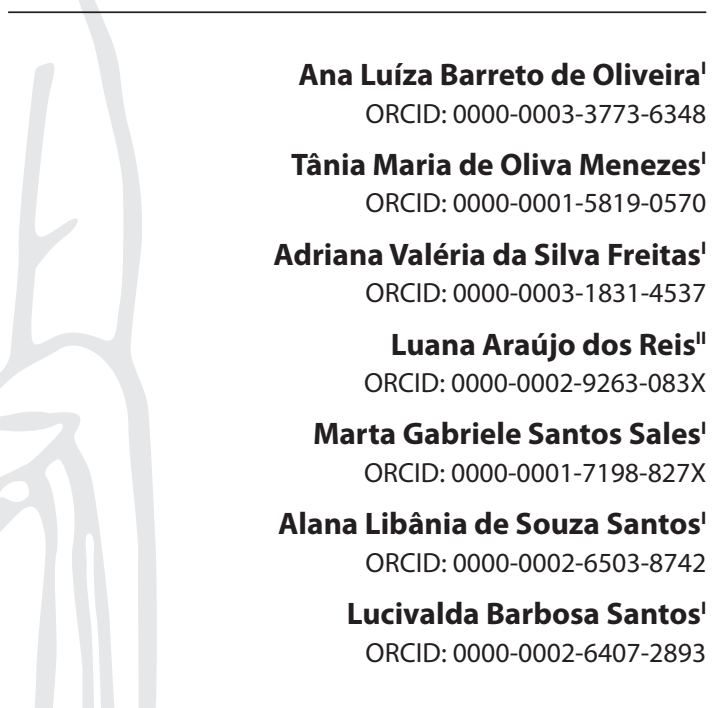

'Universidade Federal da Bahia. Salvador, Bahia, Brazil. "Faculdade Independente do Nordeste. Vitória da Conquista, Bahia, Brazil.

How to cite this article: Oliveira ALB, Menezes TMO, Freitas AVS, Reis LA, Sales MGS, Santos ALS. Elderly people's experiences in emergencies through access to other levels of health care. Rev Bras Enferm. 2021;74(Suppl 2):e20200423. doi: http://dx.doi.org/10.1590/0034-7167-2020-0423

\section{Corresponding author: \\ Tânia Maria de Oliva Menezes \\ E-mail: tomenezes50@gmail.com}

EDITOR IN CHIEF: Antonio José de Almeida Filho ASSOCIATE EDITOR: Fátima Helena Espírito Santo

Submission: $07-09-2020$

Approval: 09-24-2020

\section{ABSTRACT}

Objective: to understand elderly people's experiences in emergencies through access to other levels of health care. Methods: a phenomenological study in the light of Heidegger, conducted with 19 elderly patients admitted to an Emergency Care Unit of the city of Salvador, between April and October 2019. Results: ontic primacy: Disposition of the experience of elderly people waiting for regulation; Constitutional anguish and fear in the willingness to be an elderly person waiting for regulation in an Emergency Care Unit; Inappropriate elderly being suppressed while waiting for regulation; Being an elderly person unveiled in the existential modality of being for death. Ontological primacy: Heal how to be the presence of elderly people waiting for regulation. Final considerations: elderly people being anguished and afraid, feelings that allow the questioning of their own being, who want a healing and seeks ways that allows an active and proper participation in care.

Descriptors: Health Services Accessibility; Aged; Emergencies; Secondary Care; Philosophy, Nursing.

\section{RESUMO}

Objetivo: compreender o vivido pelo idoso nas emergências pelo acesso para outros níveis de atenção à saúde. Métodos: estudo fenomenológico à luz de Heidegger, realizado com 19 idosos internados em Unidade de Pronto Atendimento do município de Salvador, entre os meses de abril e outubro de 2019. Resultados: primado ôntico: Disposição do vivido da pessoa idosa à espera pela regulação; Angústia e medo constitutivos na disposição de ser idoso à espera pela regulação em Unidade de Pronto Atendimento; Ser idoso impróprio suprimido na espera pela regulação; Ser idoso próprio desvelado na modalidade existenciária de ser para a morte. Primado ontológico: Cura como ser da presença da pessoa idosa à espera pela regulação. Considerações finais: o ser idoso se angustia e tem medo, sentimentos que permitem o questionamento do próprio ser, que deseja a cura e busca caminhos que permite uma participação ativa e própria no cuidado.

Descritores: Acesso aos Serviços de Saúde; Idoso; Emergências; Atenção Secundária à Saúde; Filosofia em Enfermagem.

\section{RESUMEN}

Objetivo: comprender lo que viven los ancianos en situaciones de emergencia a través del acceso a otros niveles de atención de la salud. Métodos: estudio fenomenológico a la luz de Heidegger, realizado con 19 pacientes ancianos ingresados en la Unidad de Urgencias de la ciudad de Salvador, entre los meses de abril y octubre de 2019. Resultados: primacía óntica: disposición de la experiencia del anciano en espera de regulación; Angustia constitucional y miedo ante la voluntad de ser un anciano en espera de regulación en una unidad de emergencia; Ancianos inapropiados reprimidos mientras esperan la regulación; Ser un anciano desvelado en la modalidad existencial del ser para la muerte. Primacía ontológica: Cura cómo ser la presencia del anciano esperando la regulación. Consideraciones finales: el anciano está angustiado y asustado, sentimientos que permiten el cuestionamiento de su propio ser, que quiere una cura y busca caminos que le permitan una participación activa y adecuada en el cuidado.

Descriptors: Acceso a los Servicios de Salud; Anciano; Emergencias; Atención Secundaria de Salud; Filosofia de Enfermería. 


\section{INTRODUCTION}

The aging process in Brazil has been gradually increasing due to changes in the last 30 years, which are due to reduction in fertility rates and increase in life expectancy ${ }^{(1)}$. With this increase in life expectancy, the elderly population growth affected by several comorbidities and chronic diseases, the emergency service has been the main access of these users to health care, highlighting the need to change the care paradigm ${ }^{(2)}$.

This phenomenon is accompanied by distortion of the purpose of Emergency Care Units (ECUs), transformed in practice into short-term inpatient units for clinical conditions, which end up easing lack of beds instead of intending it ${ }^{(3)}$.

When citing care for elderly people, this service must be quick, as the aging process, which is often accompanied by comorbidities, makes the aging person more susceptible to the appearance of complications and, consequently, disabilities, compromising quality of life (QoL), including leading them to death ${ }^{(4)}$.

Thus, in the light of phenomenology, the following guiding question was raised: how have experiences by elderly people in emergencies been waiting for the regulation of access to health services?

When entering into elderly people's experiences in emergencies waiting for the regulation of access to health services, it is possible to understand how this being behaves, relates and disposes itself in face of the studied phenomenon. This occurs in the perspective of knowing the original way of being elderly that waits for regulation to other levels of health care, in order to enable alternative ways of improving the quality of access in the public health service through the statement of those who experience the problem.

In this context, the practices of care for elderly people performed by nurses in emergency services are challenging, as they need to be directed towards adapting the routine and organizing work in this environment, to meet elderly people's needs ${ }^{(2)}$.

\section{OBJECTIVE}

To understand elderly people's experiences in emergencies through access to other levels of health care.

\section{METHODS}

\section{Ethical aspects}

This study was approved by the Ethics and Research Committee of the School of Nursing of Universidade Federal da Bahia, according to Resolution 466/12 and its complementary ones. To preserve anonymity, participants received letter "E", followed by the number corresponding to the order in which all interviews were conducted.

\section{Type of study}

This is a qualitative field study, with a phenomenological approach in the light of the thinking of Martin Heidegger ${ }^{(5)}$, conducted and structured based on the Consolidated Criteria for Reporting Qualitative Research (COREQ) ${ }^{(6)}$. The research is linked to the Center for the Study and Research of the Elderly-NESPI, School of Nursing, Universidade Federal da Bahia.

\section{Methodological procedures}

\section{Study setting}

The study was carried out in ECU of size III in the district of the railway suburb of the city of Salvador Bahia, which has 15 observation beds with an average service capacity of 350 patients per day for a population in the coverage area of 200 thousand to 300 thousand inhabitants ${ }^{(7)}$.

The location was chosen considering the complexity and breadth of this service in terms of the number of services, capacity per bed and the need for the regulation service. Also, the fact that the unit is located in a neighborhood where there is no coverage from the Family Health Strategy (FHS), which makes it difficult for the entire population to have full access to the health care network at their performance levels.

\section{Study participants}

Participants were invited to participate in the research, at random, according to the following inclusion criteria: 1 . Elderly people who were attending the ECU, with a request for regulation; 2. Elderly people able to establish the communication process verified through the application of the Mini Mental State Examination (MMSE). The request to participate in the study occurred with 28 elderly people, of whom eight refused to participate, with the justification of not being accompanied and not feeling safe to speak without the presence of a family member and/or acquaintance (two elderly people), and for indisposition due to the health condition (six elderly people).

There were 20 individuals who agreed to participate, one of whom was excluded for not being at least 60 years old, characterized as defining elderly people for developing countries. This participant was invited to participate in the research due to his bed identification informing the age of 60 years. During sociodemographic data collection, it was possible to identify that he was not yet 60 years old, not meeting the inclusion criteria. At the end, the study comprised 19 participants.

The interviews were not scheduled, as these were people who were in a condition of hospitalization waiting for access to other levels of health care, and their stay in the unit was limited, making the chance of a moment prior to the interview maybe it couldn't happen. Due to the characteristic of the study, no pilot test was performed, realizing that the understanding of the phenomenon could come from the first contact.

\section{Data collection and organization}

The information was collected, between April and October 2019, through the phenomenological interview, using face-toface encounter technique with the triggering question: how have you lived waiting for regulation here at ECU?

The understanding of the phenomenon has already started to be present since the observation of the researcher in the way elderly people person were willing, their gestures, their attunement in mood, their way of receiving the researcher. Linked to this moment, the reading of the Informed Consent Form allowed an opening for 
dialogue about the object of study, making it possible to remove doubts and establish trust through security in the researcher's statement with the hospitalized elderly person. In phenomenological research, during this contact, the researcher is already part and is already launched in the world surrounding elderly people.

The original form of coexistence with the phenomenon comes through the opening of these characteristics, which allow an ontological nexus for understanding and interpretation of being ${ }^{(5)}$. Thus, the interviews took place in bed, considering the mobility difficulties of the study participants. Conducting interviews in the very environment in which elderly people experience waiting for regulation can be considered as part of the world surrounding the being, thus allowing their way of being disposed in that world.

The difficulties faced in apprehending the statement of the participating entities were related to the noise of the sector. In order to soften their exposure and make the place more appropriate, curtains that separate the beds were used, as well as interviews in the afternoon, characterized by less circulation of people and procedures by health professionals. When the researcher was going to conduct the interview, she informed a nurse that she would be with a patient, so that there would be no interruption and the interviews were conducted without any interruption.

At the meetings, all elderly people were accompanied by a relative/family member or close acquaintance in bed. The terms of the research and interview had also been explained, as well as the importance of non-interference during the same. In the triggering question, an accessible opening was allowed from elderly people's understanding of the investigative question. At that moment, the participants felt free to talk about what they understood about the experiences waiting for regulation in ECU.

Even though they sometimes do not know how to explain the concept of regulation, everyone allowed, through statement, the opening articulated in meanings and meaning about experiences of waiting. Even in bed, the conduct of the interviews took place with ease and fluidity between the study participants and the researcher.

The interviews were recorded using the recording device of a smartphone's mobile device, and the duration varied between six and twenty-two minutes. The transcripts of the interviews were made by a single researcher, the same one who conducted the interviews. It is noticed that, in the search for the phenomenon, the greater the researcher's proximity to all stages of the study, the better their understanding and interpretation.

The saturation of the testimonies occurred as the repetition of the information enabled a vague and average understanding of the issue of this being in their daily lives, waiting for regulation to other levels of health care in ECU. However, it is important to highlight that in the study of phenomenology, the repetition of information, experiences, statements of elderly people do not culminate in exhausting the possibilities and ways of being an elderly person waiting for regulation, and, yes, showing a type of path, of innumerable paths and meanings existing on this experience.

\section{Data analysis}

The methodological sense of the phenomenological description is understanding (ontic primacy) and interpretation (ontological primacy), which allows to reveal the sense of being and the fundamental structures of presence ${ }^{(5)}$.

The projecting of understanding corresponds to the plane of material, physical existence, i.e., where we live the here and now, the being opens up in its possibility through the units of meaning and, is ontologically available to a rich and varied interpretation of oneself and their ways of being on each occasion and through units of meaning ${ }^{(5)}$.

Thus, in the first moment, what is determined by the statement of elderly people person who waits for access to other levels of health care is constituted by the disposition, by attunement in mood as that being is. From this understanding, albeit vague and average, it is possible to mean the statement of this being, through the interpretation of the ways in which it appears.

\section{RESULTS}

Of the 19 participants, ten were female and nine male, with a predominance of the age group from 60 to 69 years old, represented by 16 elderly people and with a smaller number (three) between 70 and 79 years old. All participants reported seeking ECU due to health problems, with emphasis on symptoms of hypertension, diabetes mellitus, acute myocardial infarction, stroke and hemorrhages.

The phenomenological study allowed to submerge in the way elderly people live waiting for regulation in ECU, because, through statement, it was possible to understand the way elderly people are disposed about the investigated phenomenon through the following units of meanings:

\section{Unit of Meaning 1: Disposition of the experience of elderly people waiting for regulation}

I think it is bad to wait. (E2)

I am anxious for the regulation to go soon, so that I can treat this leg. (E5)

I have bad experiences, because here we wait for regulation. Oh, the regulation never comes, it never comes and we stay here. So, it has to be a faster business and it takes a long time. (E6)

It is so worrying, because it has some problems for me. The person is anxious. (E09)

I get a little nervous, but we really have to wait. (E10)

She gets anxious, gets worried. (E12)

Pass me through hunger. I'm not even eating properly. [...] and I don't feel well, I'm not feeling well here. (E13)

I don't sleep well worried, I'm not in the mood to eat, because I just want you to solve it soon, that my regulation will come soon. Very anxious and nervous. I'm getting depressed. (E14)

It's been seven days already, I think it's a long time, as this regulation should have gone out. (E17)

I wake up four hours and stay here at dawn and then I don't sleep anymore. I get anxious. It is very difficult, because we wait, wait and do not arrive. (E19) 
Attunement in mood refers to the way elderly people are willing to wait for regulation to other points of health care. Worry, anxiety, nervousness, changes in sleep and eating patterns are some of the ways to make waiting a bad unpleasant experience. However, there was a participant who had the meaning of waiting as something normal, peaceful and part of life.

And it's normal, I'm waiting. I'm waiting calmly [laugh]. (E1)

With patience, isn't it? (E3)

Waiting is a normal thing because there must be another one needing more than me (E16)

This disposition shows that the experience of waiting can also be lived as something common in everyday life.

\section{Unit of Meaning 2: Constitutional anguish and fear in the willingness to be an elderly person waiting for regulation in an Emergency Care Unit}

Despite the desire to be regulated, anguish and fear were reported by the participants as modes of disposition when regulation is expected:

I'm going to ask the doctor, right? A tranquilizer, for me to calm down. (E2)

Going home will be much better, because I will feel ten times better than I was. (E7)

It is so worrying, and already at an advanced age. I wanted me to leave here to go to my home. Unfortunately, the SUS system leaves these concerns. (E9)

It tookme 25 days when I came here with a foot problem and from there for the time I was waiting for the regulation, it evolved, and after I was regulated I went to the operating room to amputate my left foot. I don't have half my left foot. We stay here without knowing what will happen, to which hospital it goes. (E12)

I never stayed out of the house like that, so when you got here eight days ago. Then I feel bad. (E13)

I am afraid. (E15)

I get scared like that to see if they will leave me here, if I'm going to leave or if I'm going somewhere else. (E18)

Elderly people demonstrated a willingness to be afraid of regulation through feelings of anguish, anxiety, nervousness and concern, which leads them to be available in different ways, ranging from discomfort that waiting causes, vulnerability in acquiring other diseases, worsening illness and feeling of not belonging to the place where they are hospitalized. The fear imposed by the surrounding world reveals the ways of being of elderly people.

\section{Unit of Meaning 3: Inappropriate elderly being suppressed while waiting for regulation}

My problem has already been addressed, because God with his powerful hand improved my situation. (E7)
I will be assisted in the name of Jesus. (E8)

God's plan only God knows, so you have to accept it. (E12)

God only knows if I'm going to be lucky, because it's lucky for me. I've been asking God for strength and for him to help me. (E14)

Religion and religiosity have proven to constitute, for this fear of not being able to be together, at the same time a tool of support, emotional support and resilience, as well as mitigating for pointing out a conformist attitude of accepting the facts and handing them over to the hand of God, so that this may be the precursor of their destiny.

In addition to religion, the world's obligations around them also reveal a way of being inappropriate, where pre-occupation with family members, household chores ends up overlapping a concern with their current health problem, according to the statements below:

I am worried about my grandchildren, with whom the children will stay, because I take care of them. (E12)

Because I'm already used to taking my bath at night, during the day I'm doing my little things, cleaning and tidying my house. (E13)

I think that tomorrow I will leave here, in the name of Jesus. I have no way of going away because of my son and grandchildren. (E15)

Ah, I want to go home to do my stuff [...] wash my clothes, cook my food, sweep my house, talk to my colleagues down the street that I am a good friend and even sleep at night. (E19)

These possibilities of being impersonal, that presence behaves in the surrounding world, are what allow us to understand and interpret the proper way of being.

\section{Unit of Meaning 4: Being an elderly person unveiled in the existential modality of being for death}

For some participants, waiting too long to be regulated can mean death, according to the statements below:

There are people who even die in line. (E07)

Many people die waiting for this regulation. (E15)

However, when elderly people perceive the outcome for death in the delay of regulation, they become aware of the will to emancipate their state of health, allowing themselves to be met with their own way, who want a different outcome for their life, fighting for alternative ways to streamline regulation:

What you can do is someone help me, understand? As there are already people wanting to help me with the role of these doctors who take care of this, understand? There are a lot of people who can help me. (E4)

Because my daughter really found someone who works in regulation [...] if she finds it easier, it is better. (E12)

And my family is also moving around outside to see if, through friends, they can bring someone, a doctor from a hospital, to request my departure soon, so that I can do my amputation and stay calm. They are moving their fingers. (E14) 
Here, elderly people launch themselves into their own possibility of being regulated, which is through proximity, bonding with health professionals, who can make regulation faster, connoting the possibility of another mode of disposal, in which elderly people may have control over their health situation.

Through the units of meaning, it became understandable, from the origin of the indicated meanings, to elucidate that elderly people's experiences in waiting reveals a being who longs for healing after the encounter with themselves. Such dispositions could lead to ontological hermeneutics about the being.

\section{Unit of Meaning: Heal how to be the presence of elderly people waiting for regulation}

Healing enters as an existential possibility of the desire to be one's own, which is concerned with the resolution of their health problem, either through hospital discharge or through regulation for another health unit that happens in a timely manner, so that this being return to their everyday occupations.

\section{DISCUSSION}

Elderly people mean the experiences waiting for regulation as something bad and time consuming, leading to changes in daily life, such as inadequate diet and altered sleep pattern, promoting behavior change, linked to feelings of anxiety and concern, which can compromise QoL.

The hospital experience of hospitalized patients brings positive and negative aspects. Among the negatives stand out: sleep alteration, diet and feeling of anxiety due to waiting ${ }^{(8)}$.

Hospitalized elderly can, in most cases, present nutritional alterations, with a significant prevalence of malnutrition or at risk of malnutrition, which can lead to complications such as edema in the limbs, oliguria and pressure ulcers ${ }^{(9)}$ and become vulnerable when faced with the hospital environment, which can be stressful(10).

In this context, the environment of a health institution ends up being configured, sometimes, in a space of exercise of power, in which it imposes procedures and technological equipment unknown to the patient, who is able to accept this condition, believing that this will lead them to solve the health problem, even if it brings a certain type of suffering or contradicts their will(11).

Passivity in coping can be related as a way of facing prolonged waiting, which can decrease anxiety and fear of what is to come.

By being disposed of in acceptance, they unveil the phenomenon of self-escape, which is when the presence ends up not standing before them, distancing themselves from their own power-being. This fact is characteristic of fear, because fear opens up in the set of its dangers, abandonment to "oneself"(5).

Fear and anguish constitute openness as a disposition, revealing how it is ${ }^{(5)}$. Such a disposition is a way of being thrown in a vulnerable way into the world, because in anguish it is strange and strangeness also means not feeling at home. This strangeness constantly pursues the presence and threat, with daily loss in the impersonal ${ }^{(5)}$.

The way of being impersonal/inappropriate ends up not portraying something specific to one, but something that may be present in a"whole" by the overlap of the surrounding world, called Heidegger ${ }^{(5)}$ as worldliness. Having something to do and produce something exemplifies the countless possibilities of the way of being in the world, which have the way of being of occupation ${ }^{(5)}$.

Elderly people, in their daily lives, are busy and "pre" carry out daily obligations, such as caring for family members and household tasks, which end up overlapping their current health problem. This is a way of being close to. They are afraid of what could come suppressed ${ }^{(5)}$ with this wait.

For Heidegger, fearing for the house or property demonstrates that, as a being-in-the-world, presence is a being in occupations next to, understood in what one is afraid of, as a threat of not being able to be next to ${ }^{(5)}$.

The religious aspect is also present in the meaning of waiting, in which it unveils the way this being expects, providing for this being hope and faith as tools of coping, resilience for prolonged waiting and even conformism for prolonged waiting.

Thus, in a first approach and, in most cases, the presence succumbs to the impersonal and allows itself to be dominated by it; however, it is precisely what is deviated, what is impersonal, that the presence runs after. Presence is essentially placed before itself only through a constitutive opening, when it flees from itself $f^{(5)}$.

The possibilities of being that the presence, as impersonal, opened and appropriated should be drawn from an analysis of the understanding and interpretation of the impersonal ${ }^{(5)}$. Anguish is one of the ways for this being-there to be exposed, because of what causes fear it allows an existential analysis and the capacity for openness in its being ${ }^{(5)}$.

By being in the way of being-to-death, the existence modality of being of one's own presence is unveiled only as something to come. Future means an advent in which presence comes to itself in its power-being more own ${ }^{(5)}$. This phenomenon of the coming is what Heidegger calls temporality, and the original unity of the healing structure ${ }^{(5)}$.

It is precisely from what is diverted, which is impersonal, that presence goes after. Presence is essentially placed before itself only through a constitutive opening, when it flees from itself ${ }^{(5)}$.

This moment represents a basic existential mode of opening that is also originally from the world, from co-presence and existence, representing a way in itself of being in the world, i.e., the world that has already opened leaves and makes the intramundane being to meet ${ }^{(5)}$.

This facticity is not the fact of a being simply given, but an ontological character of the presence assumed in existence, although repressed in the beginning ${ }^{(5)}$. In the mode of being tuned in humor, the presence sees possibilities of reaching itself, i.e., of the being-in-the-world launched in projects ${ }^{(5)}$.

Statement is language because that person, whose openness is articulated in meanings, is cast and sent in the world, and this statement constitutes the saying of desires, in which the presence is pronounced ${ }^{(5)}$.

Existentiality provides the ontological constitution of selfawareness of presence, which is a phenomenal soil originating from the question about the "I" being, the meaning of this being originally constitutes the being of being-able ${ }^{(5)}$.

The being of the power-being is the sense of healing that enables the constitution of being of an entity ${ }^{(5)}$. Thus, "what is pronounced is precisely being outside, i.e., the increasingly different mood that, as indicated, reaches every opening of being-in."(5). 
In this way, phenomenology comprises being in the world, showing the being of an entity, its senses, its modifications and derivatives, revealing the way of being specifically human based on their temporality.

The modes of signification revealed an improper being-in-theworld absorbed in occupations with intramundane entities and impersonally tutored by the conformity of waiting for regulation, to the point of becoming inattentive with their health condition and conceiving their situation as something simply given.

This being-in-the-world, in the ontic primacy, which corresponds to this first moment of disposition of the being, seems to be so decadent the impropriety of the domain of knowledge about health care, which suggests that it is doomed to the medianity of the facts.

It is precisely in the most indifferent daily life that elderly people can break with a way of being passive and behave in order to be more active. When faced with the unknown, without knowing where they are going and what the outcome of this waiting will be, elderly people are exposed to feelings, sometimes little visited, such as fear and anguish, but which allow the fruitful experience of being presented to oneself, and so to their original and ontological way of being for healing.

In the fundamental analysis of the presence, hermeneutics, oriented in the ontological primacy, of being elderly demonstrated in their statement the desire to re-establish their health. In a concrete way, it seeks to know the tools necessary for this to occur, such as the help through the bond formed with health professionals.

Maintaining good interpersonal relationships with professionals from different points of the emergency and emergency network is considered a facilitating strategy for user access from one service to the other ${ }^{(12)}$.

This construct implies that regulation is a social production that encompasses multiple regimes, and that the layman's actions take on a nuance of "control" over their health situation and that it can be seen as a type of regulatory regime ${ }^{(13)}$.

This way of being leads to possible paths that make it possible to improve elderly people's health condition through a more participatory being with property over their health condition.

\section{Study limitations}

The study was developed in only one of the nine ECUs existing in the city of Salvador. Thus, the setting unveils the experience of a specific group of the network, pointing to the need to broaden the gaze in front of the other units.

\section{Contributions to nursing}

Nursing plays an important role in the knowledge of the desire of its users, because, when knowing the world of the one who cares, it has the possibility of carrying out a therapeutic plan based on establishing co-participation of users and system.

Communication between health professional and user is an important tool for establishing an active bond, as well as to allow the pronouncement of this desire, i.e., the opening of this being, through their statement and through shared knowledge about hospital practices among those involved in the care process.

Thus, since welcoming with risk stratification, it is important that nurses elucidate for users, especially elderly people, the setting they are in, their real health situation and what measures are being taken in relation to their condition. Their driving within the unit itself needs to be clearer as to the reasons for hospitalization, the reason for waiting and the daily update on the events that permeate the network. This goes from guidance on activities of daily living to empowerment of knowledge of the tools used in the health system, ranging from medicines, exams and the need to transfer to other services to preserve and maintain their lives.

\section{FINAL CONSIDERATIONS}

The plurality of the modes of existence of being elderly own and inappropriate waiting for the regulation in ECU described in the units of meaning are contained in the ontic primacy, in the way this being is disposed. From the understanding of this disposition, it allowed us to enter the ontology, which interprets this statement in the structure of healing, Unit of Meaning unveiled in the technical temporality of being studied.

The scope of phenomenological analysis proposed by Heidegger is not intended in the solution of the studied phenomenon, but rather in the permission to unsee a multiform variety of ontological characteristics constitutive of elderly people waiting for regulation, in order to show the originality of the theme studied.

Regulation is still an unfamiliar tool for elderly people hospitalized in ECU, and because it is not known, it becomes something distant, not present in its reality. What is distant gives us no idea of belonging. This refers to a passive posture in the face of health care, in which the subject is in fact a patient of health actions.

Those who had minimal knowledge about regulation and their health situation were more participative about these conditions, besides being more mobilized in finding plausible alternatives to solve the problem.

\section{REFERENCES}

1. Silva PLN, Veloso NEB, Tele MAB, Oliveira KCF, Oliveira MKS, Alves ECS. Profile of the hospitalized elderly companion: evaluation of the performance in the care and geriatric recuperation. J Health Biol Sci. 2018;6(1):48-53. doi: 10.12662/2317-3076jhbs.v6i1.1445.p48-53.2018

2. Andrade LAS, Santos SP, Corpolato RC, Willig MH, Mantovani MF, Aguilera AL. Elderly care in the emergency department: an integrative review. Rev Bras Geriatr Gerontol. 2018;21(2):243-53. doi: 10.1590/1981-22562018021.170144

3. Konder M, O'Dwyer G. Emergency Care Units as hospitalization units: phenomena of the care flow in the emergency network. Physis. 2019;29(2):e290203. doi: 10.1590/s0103-73312019290203 
4. Santos CTB, Andrade LOM, Silva MJ, Sousa MF. Course of the elderly in health care network: a link to be built. Physis. 2016;26(1):45-62. doi: $10.1590 /$ S0103-73312016000100005

5. Heidegger M. Ser e Tempo. Rio de Janeiro: Vozes; 2017. 600 p.

6. Tong A, Sainsbury P, Craig J. Consolidated criteria for reporting qualitative research (COREQ): a 32-item checklist for interviews and focus groups. Int J Qual Health Care [Internet]. 2007 [cited 2020 Jul 01];19(6):349-57. Available from: https://academic.oup.com/intqhc/ article/19/6/349/1791966

7. Ministério da Saúde (BR). Portaria no 10 de 3 de Janeiro de 2017. Ministério da Saúde. Redefine as diretrizes de modelo assistencial e financiamento de UPA 24h de Pronto Atendimento como Componente da Rede de Atenção às Urgências, no âmbito do Sistema Único de Saúde. Brasília [Internet]. 2017 [cited 2020 Mar 10]. Available from: https://bvsms.saude.gov.br/bvs/saudelegis/gm/2017/ prt0010_03_01_2017.html

8. Florisbal GS, Donelli TMS. Reliving losses: a study with hospitalized patients at a hospital unit. Rev SBPH [Internet]. 2017[cited 2020 Mar 05];20(1):75-98. Available from: http://pepsic.bvsalud.org/scielo.php?script=sci_arttext\&pid=S1516-08582017000100006\&lng=pt

9. Brock F, Bettinelli LA, Dobner T, Stobbe JC, Pomatti G, Telles CT. Prevalence of hypoalbuminemia and nutritional issues in hospitalized elders. Rev Latino-Am Enfermagem. 2016;24:e2736. doi: 10.1590/1518-8345.0260.2736

10. Meneguini S, Banjaii PFT, Ferreira MLS. Care for hospitalized elderly patients: implications for nursing team. Rev Enferm UERJ. 2017;25:e16107. doi: 10.12957/reuerj.2017.16107

11. Baptista MKS, Santos RM, Costa LMC, Macêdo AC, Costa RLM. The power in the nurse-patient relationship: integrative review. Rev Bioét. 2018;26(4):556-66. doi: 10.1590/1983-80422018264274

12. Hermida PMV, Nascimento ERP, Echevarría-Guanilo ME, Andrade SR, Ortiga AMB. Counter-referral in Emergency Care Units: discourse of the collective speech. Rev Bras Enferm. 2019;72(supl. 1):143-50. doi: 10.1590/0034-7167-2018-0023

13. Cecilio LCO, Carapinheiro G, Andrezza R, Souza ALM, Andrade MGG, Santiago SM, et al. O agir leigo e o cuidado em saúde: a produção de mapas de cuidado. Cad Saude Publica, 2014;30(7):1502-14. doi: 10.1590/0102-311X00055913 